\title{
THE SUBSTITUTIONALITY OF PRODUCTION FACTORS IN POLISH COMMERCIAL FARMS ORIENTED TOWARDS CROP PRODUCTION
}

\begin{abstract}
Renata KUBIK, Department of Economics and Agribusiness, University of Life Sciences in Lublin, ul. Akademicka 13, 20-950 Lublin, Poland, renata.kubik@up.lublin.pl (corresponding author)

Ewa WÓJCIK, Department of Economics and Agribusiness, University of Life Sciences in Lublin, ul. Akademicka 13, 20-950 Lublin, Poland, ewa.wojcik@up.lublin.pl

Anna KOBIALKA, Department of Economics and Agribusiness, University of Life Sciences in Lublin, ul. Akademicka 13, 20-950 Lublin, Poland, anna.kobialka@up.lublin.pl

Elżbieta KOLODZIEJ, Department of Economics and Agribusiness, University of Life Sciences in Lublin, ul. Akademicka 13, 20-950 Lublin, Poland, elzbieta.kolodzei@uplublin.pl

The objective of this study was to assess the substitution of labour for capital in the Polish commercial farms oriented towards crop production in the years 2009-2011. The study was developed on the basis of empirical unit data of the Polish FADN regarding commercial farms classified as the "Fieldcrops" group. The results were presented in comparison with the farms pursuing mixed production, which in the FADN are referred to as "Mixed". The study used the Cobb-Douglass production function method. Based on the flexibility ratios, reflecting the degree of proportionality of revenue in relation to the analysed factors, it can be inferred that the farms in question displayed a growing efficiency of total inputs in the reference years. However, the analysis of the substitution of labour for capital in the surveyed farms oriented towards crop production revealed less favourable results, in terms of the achievement of the economic objective in 2009-2011. The results indicate that the substitution of labour for capital in the analysed period was effective in both types of farms. The comparative analysis of the marginal rates of substitution reveals that the substitution of labour for capital was more favourable in the "Fieldcrops" group than in the "Mixed" type farms in 2011. In order to substitute one man-hour, an average "Fieldcrops" farm had to increase its capital by PLN 5.98 in 2009, by PLN 6.88 in 2010 and by PLN 2.55 in 2011 whereas in the "Mixed" type farm it was PLN 2.12, PLN 2.91 and PLN 2.89, respectively.
\end{abstract}

Keywords: Cobb-Douglas production function, commercial farms, production factors.

\section{INTRODUCTION}

Poland is a country where agriculture, and especially crop production, plays a vital role. The share of crop production in the total agricultural output amounted to $52.2 \%$ in 2009, $53.2 \%$ in 2010 and to $56.3 \%$ in 2011 (The Statistical Yearbook..., 2012, 2014). Attempts at production specialisation in the farms oriented towards crop production have allowed the mechanisation of production processes and the lowering of costs, including especially those of human labour. Nevertheless, animal production forms an integral part of crop production, ensuring the proper balance of production factors (Mickiewicz, 2012). In view of the above, this study seeks to analyse the commercial farms oriented towards crop production in comparison with the so-called mixed farms, that deal with both crop and animal production.

Changes to the production factors correlation inside farms, which can let them achieve and maintain a dynamic balance, should be prevalent in the process of the Polish agriculture development (Woś, 2003). According to production theory, the farms that aim at profit maximisation may select such a combination of the production factors that will let them attain the desirable production level by incurring the lowest possible inputs (Zellner et al., 1966). Therefore, in view of the intended production efficiency, it appears crucial to set the accurate proportions of the inputs of production factors. The agricultural production function, determining the relationship between the production volume and those production factors that are necessary to achieve it, enables the establishing of the relevant combination of inputs of production factors, in order to minimise the costs at a given production level (Heady and Dillon, 1961).

All commercial farms, including those oriented towards crop production, undergo concentration and specialisation processes, implement technical and production innovations, and search for less expensive production and operational methods. In consequence, assuming the satisfactory level of agricultural and inter-sector mobility of production factors engaged in agriculture, the substitution of labour and land by capital becomes profitable, and the inflow of capital can be used effectively (Szulce, 2001). The optimal use of the production factors, including especially labour, constitutes a major agricultural policy objective, referred to in Article 39 of the Treaty of Rome. The ideal 
competition between farms operating in the bio-product market entails the necessity to improve production efficiency, for instance, by minimising production costs (Wójcik, 2005). This can be done through substituting human labour with capital.

The objective of this study is to compare and assess the substitution of labour for capital in the Polish commercial farms, classified as "Fieldcrops" (F) or "Mixed" (M) according to the Polish FADN, in the period 2009-2011.

\section{MATERIALS AND METHODS}

Numerical data for 2009, 2010 and 2011, regarding farms from the field of observation of the Polish FADN, were used in the empirical studies. The FADN provides a database in which data are collected using consistent methods, with the farms constituting a statistically representative sample of commercial farms operating within the EU area, which ensures data comparability. The number of commercial farms of the "Fieldcrops" type amounted to 2110 in 2009, 1911 in 2010, and to 2024 in 2011. As regards the "Mixed" type farms, it was 3990, 3668 and 3579, respectively. These numbers were sufficient to effectively employ the Cobb-Douglass production function method (Jaworski, 1972).

The relationship between the input of production factors and output is referred to as the production function (Miller, 2008), given that the former tends to be limited to human and objectified labour. Two approaches have been applied in determining the variables used in the production function approximation. One of them entails presenting the input through resources, and the other involves shifting the attention from the resource-oriented aspects of farming activity (i.e. employment and the value of fixed assets) to the categories that display a flowing character (Kalinowski, 2002). A special focus of this study is on the dual production function, combining labour and capital (Heijman et al., 2007). To achieve the set objective, the study employed the Cobb-Douglass production function method, which constitutes the theoretical basis for clarifying most efficiency regularities in agricultural economics (Bezat and Rembisz, 2011). For several years, the Cobb-Douglass production function has been widely used in econometric studies (Aggelopoulos et al., 2006; Ionita and Andrei, 2010; Yuan, 2011; Kotulič and Pavelková, 2014). This study used the following formula:

$$
Y=a X_{1}^{\alpha} X_{2}^{\beta} d
$$

$\mathrm{a}-$ constant (total production factors efficiency),

$\mathrm{Y}$ - total output in PLN (according to the Polish FADN - SE131) ${ }^{1}$,

$\mathrm{X}_{1}$ - total labour input in man-hours ${ }^{2}$ (SE011),

$\mathrm{X}_{2}$ - total inputs in $\mathrm{PLN}^{3}$ (SE270),

$\alpha, \beta$-regression coefficients,

$\mathrm{d}-$ random factor.

The calculations were conducted using GRETL ${ }^{4}$.

\section{RESULTS AND DISCUSSION}

The statistical characteristics of the numerical data, comprising names, feature types according to the Polish FADN, arithmetic means and coefficients of variation, are presented in Table 1. Type symbols are used consistently throughout the study.

Table 1. Statistical characteristics of analyzed variables of "Fieldcrops" and "Mixed" in the years 2009-2011 in Poland

\begin{tabular}{|c|c|c|c|c|c|c|}
\hline \multirow[b]{2}{*}{$\begin{array}{l}\text { Feature } \\
\text { name }\end{array}$} & \multirow[b]{2}{*}{$\begin{array}{c}\text { Features according } \\
\text { Poland FADN }\end{array}$} & \multirow[b]{2}{*}{ Unit } & \multicolumn{2}{|c|}{ "Fieldcrops" } & \multicolumn{2}{|c|}{ "Mixed" } \\
\hline & & & Arithmetical mean & \begin{tabular}{|c|} 
Variability coefficient \\
{$[\%]$}
\end{tabular} & $\begin{array}{c}\text { Arithmetical } \\
\text { mean }\end{array}$ & $\begin{array}{c}\text { Variability } \\
\text { coefficient [\%] }\end{array}$ \\
\hline \multicolumn{7}{|c|}{2009} \\
\hline Total output & SE131 & PLN & 200447 & 122.41 & 123187 & 112.98 \\
\hline Labour input & SE011 & $\mathrm{h}$ & 4313 & 77.21 & 4120 & 46.08 \\
\hline Total inputs & SE270 & PLN & 181696 & 113.47 & 110260 & 110.70 \\
\hline \multicolumn{7}{|c|}{2010} \\
\hline Total output & SE131 & PLN & 255118 & 118.20 & 144237 & 116.72 \\
\hline Labour input & SE011 & $\mathrm{h}$ & 4432 & 68.58 & 4283 & 48.82 \\
\hline Total inputs & SE270 & PLN & 186214 & 113.52 & 114919 & 115.45 \\
\hline \multicolumn{7}{|c|}{2011} \\
\hline Total output & SE131 & PLN & 279888 & 117.77 & 167396 & 116.27 \\
\hline Labour input & SE011 & $\mathrm{h}$ & 4423 & 69.03 & 4265 & 50.59 \\
\hline Total inputs & SE270 & PLN & 209564 & 114.45 & 131664 & 113.27 \\
\hline
\end{tabular}

Source: Own study based upon unit empirical data from Polish FADN

\footnotetext{
${ }^{1}$ SE131 - this item corresponds to the charge for engaging production factors in the operational activity of a farm, irrespective of their ownership status (external or internal).

${ }^{2}$ SE011 - this item reflects total human labour time in the operational activity of a farm, expressed in hours.

${ }^{3}$ SE270 - this item covers specific costs, overheads, depreciation and external factors.

${ }^{4}$ Gnu Regression Econometrics Time-Series Library, i.e. software developed by Allin Cottrell from Wake Forest University in North Carolina, USA.
} 
The analysis of Table 1 reveals that the variation of features was higher in almost all cases, in the reference years, in the commercial farms of the "Fieldcrops" type than in the "Mixed" type farms. The highest variation was recorded in total output and total inputs whereas total labour appeared to be the least variable feature in both types of farm. This results from the prevalence of family-owned farms in Poland, in which the input of labour depends on the number of family members. The comparison of the average variable sizes in both types of farm indicates that total output, total costs and total labour were higher in the farms classified as the "Fieldcrops" group, as compared to the "Mixed" type farms. However, it is worth noting that, in the reference period, the total dynamics of output recorded in the "Mixed" farms was lower $(136 \%)$ than in the "Fieldcrops" type farms (140\%). The dynamics of the average level of total costs was higher in the former group (119\%) as compared to the latter $(115 \%)$ while the input of labour remained at the almost same level in both types of the commercial farms surveyed.

The features presented in Table 1 provided the basis for developing the agricultural production equations in the types of farms being compared. The Cobb-Douglas function model was approximated for the Polish commercial farms of the "Fieldcrops" and "Mixed" types, for the period 2009-2011. Those models, expressing the relationship between total output in PLN (SE131), constituting a dependent variable, as well as total labour input in man-hours (SE011) and total inputs in PLN (SE270), forming independent variables, were expressed through the following equations:

I. "Fieldcrops

2009: $\mathrm{SE} 1311^{\prime}=0.4253 \mathrm{SE} 011^{0.1390} \mathrm{SE} 270^{0.9797} ; \mathrm{R}^{2}=0.9016$

2010: $\mathrm{SE} 131^{\prime}=0.5407 \mathrm{SE} 011^{0.1578} \mathrm{SE} 270^{0.9646} ; \mathrm{R}^{2}=0.8769$

2011: $\mathrm{SE131}{ }^{\prime}=0.9549 \mathrm{SE} 011^{0.0531} \mathrm{SE270} 0^{0.9882} ; \mathrm{R}^{2}=0.8971$

II. "Mixed

2009: $\mathrm{SE} 1311^{\prime}=0.4506 \mathrm{SE} 011^{0.0807} \mathrm{SE} 270^{1.0179} ; \mathrm{R}^{2}=0.9252$

2010: $\mathrm{SE} 131^{\prime}=0.4490 \mathrm{SE} 011^{0.1092} \mathrm{SE} 270^{1.0071} ; \mathrm{R}^{2}=0.9157$

2011: $\mathrm{SE} 1311^{\prime}=0.5677 \mathrm{SE} 011^{0.0936} \mathrm{SE} 270^{0.9996} ; \mathrm{R}^{2}=0.9305$

The contribution of individual independent variables to the dependent variable was measured using the Student's ttest and the Snedecor's F-distribution test. The results obtained indicate that the level of contribution of all variables reaches $1 \%$. The resulting equations display a high level of the function model adjustment to the actual numerical data, which is reflected in the high values of the coefficient of determination $\left(\mathrm{R}^{2}\right)$.

Based on the Cobb-Douglas function, according to which the structural parameters of a model correspond to the output flexibility ratios in relation to various factors, it should be inferred that:

a) in 2009, an increase in the input of production factors by $1 \%$ triggered a growth in output of $1.1187 \%$ on the farms classified as the "Fieldcrops" group, and of $1.0986 \%$ in the "Mixed" type farms;

b) in 2010, an increase in the input of production factors by $1 \%$ triggered a growth in output of $1.1224 \%$ on the farms classified as the "Fieldcrops" group, and of $1.1163 \%$ in the "Mixed" type farms;

c) in 2011, an increase in the input of production factors by $1 \%$ triggered a growth in output of $1.0413 \%$ on the farms classified as the "Fieldcrops" group, and of $1.0932 \%$ in the "Mixed" type farms.

Based on the above data, it can be inferred that in each of the years in question an upward efficiency trend of total production factors was observed for both types of farms. The flexibility ratios, which reflect the degree of proportionality of revenue in relation to the analysed factors, also show that the farms oriented towards field crop production achieved an increasing overall input efficiency in 2009 and in 2010 as compared to 2011. The analysis further reveals that the production growth conditions in both types of farms were less favourable in 2011 than in 2010. Considering production flexibility in relation to various inputs, it should be noted that total inputs (SE270) constitute the major factor that determines production growth, and in the reference period their contribution to the total value of the production flexibility ratio reached above $86-95 \%$ in the farm types surveyed.

The differences in the production flexibility ratios as compared to the labour and capital involved imply that we are dealing with substitution. These results show that the output growth generated on both types of farms, in the reference period, was connected with the substitution of labour for capital. The analysis of the substitution direction was conducted using an isoquant (Jaworski, 1972). The equations for isoquants were developed by transforming the previously presented functions, and displaying the SE270 item as the function of SE011 at a given level of SE131 (Samuelson and Nordhaus, 2004):

I. "Fieldcrops"

2009: $S E 270=\left(\frac{S E 131^{\prime}}{0,4253 S E 011^{0,1390}}\right)^{\frac{1}{0,9797}}$;

2010: $S E 270=\left(\frac{S E 131^{\prime}}{0,5407 S E 011^{0,1578}}\right)^{\frac{1}{0,9646}}$;
II. "Mixed"

2009: $S E 270=\left(\frac{S E 131^{\prime}}{0,4506 S E 011^{0,0807}}\right)^{\frac{1}{1,0179}}$;

2010: $S E 270=\left(\frac{S E 131^{\prime}}{0,4490 S E 011^{0,1092}}\right)^{\frac{1}{1,0071}}$; 


$$
\text { 2011: } S E 270=\left(\frac{S E 131^{\prime}}{0,9549 S E 011^{0,0531}}\right)^{\frac{1}{0,9882}} ; \quad 2011: S E 270=\left(\frac{S E 131^{\prime}}{0,5677 S E 011^{0,0936}}\right)^{\frac{1}{0,9996}} .
$$

Total output (SE131') was estimated using the output function and the average inputs of individual production factors for a given sample of farms (Niezgoda, 1986). The total output calculated for an average farm classified as the "Fieldcrops" group amounted to PLN 193,424.01 in 2009, to PLN 246,515.20 in 2010 and to PLN 270,439.80 in 2011, and for an average "Mixed" type farm to PLN 119,726.60 in 2009, to PLN 139,686.31 in 2010 and to PLN 162,666.67 in 2011. Total inputs (SE270) were calculated on the basis of total output (SE131') by assuming various labour inputs (SE011). The relationship between labour and capital is shown by the numerical data compiled in Table 2, and the resulting isoquants are presented in Figure 1.

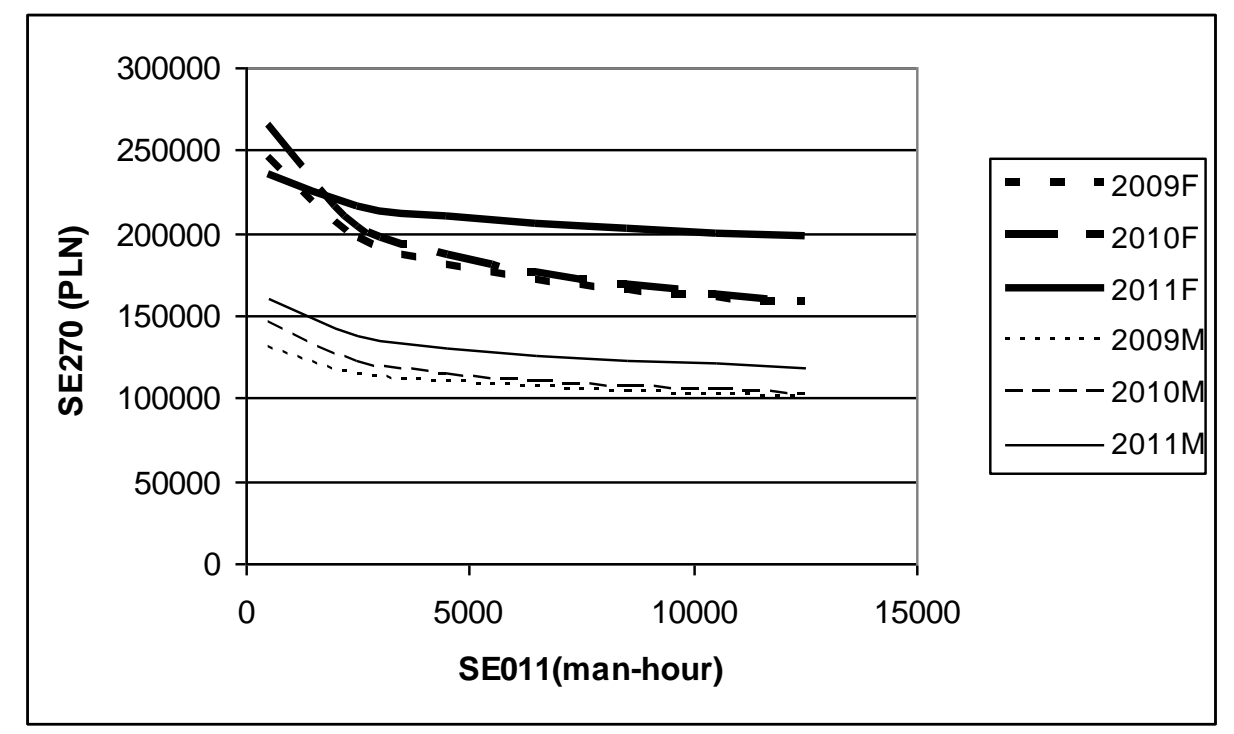

Figure 1. The isoquants of total output (SE131 in PLN) in the commercial farms surveyed, classified as the "Fieldcrops" and "Mixed" groups, in relation to total labour input (SE011 in man-hours) and total inputs (SE270 in PLN) in the years 2009, 2010 and 2011 Source: own study based on empirical unit data from the Polish FADN

The isoquants shown in Figure 1 reflect various techniques of agricultural crop production, i.e. various combinations of total labour input (SE011) and total inputs (SE270). Moving along the curves from left to right implies shifting from the labour-saving and capital-intensive production technique towards the labour-intensive and capitalsaving one. The isoquants' length was conditional on the scope of variation of the human labour factor. The graphic analysis of the regression equations shows that in 2009, in 2010 and in 2011 the isoquant determined for "Fieldcrop" farms was located further from the coordinate origin than the isoquant for the "Mixed" farms. This suggests that the conditions of the substitution of labour for capital were more favourable in the former type of farm. It can also be noted that, at a given level of output, an increased use of one of the production factors results in a decreased demand for the other. The substitutionality degree of production factors is defined as the marginal rate of substitution, i.e. "the number of units of one factor necessary to replace a unit of another factor, in order to maintain the same level of output" (Heijman et al., 2007). Considering the above, the marginal rates of substitution, which are the primary derivatives of isoquants, were used further in the analysis (Klein, 1965). The equations for the marginal rates of the substitution of labour for capital for both types of farm in the analysed period are as follows:

I. "Fieldcrops"

$$
\begin{aligned}
& \text { 2009: } \frac{\triangle S E 270}{\Delta S E 011}=-\frac{0,1390 S E 270}{0,9797 S E 011} \text {; } \\
& \text { 2010: } \frac{\Delta S E 270}{\Delta S E 011}=-\frac{0,1578 S E 270}{0,9646 S E 011} \text {; } \\
& \text { 2011: } \frac{\Delta S E 270}{\Delta S E 011}=-\frac{0,0531 S E 270}{0,9882 S E 011} \text {; }
\end{aligned}
$$

II. "Mixed"

$$
\begin{aligned}
& \text { 2009: } \frac{\Delta S E 270}{\Delta S E 011}=-\frac{0,0807 S E 270}{1,0179 S E 011} \text {; } \\
& \text { 2010: } \frac{\Delta S E 270}{\Delta S E 011}=-\frac{0,1092 S E 270}{1,0071 S E 011} \text {; } \\
& \text { 2011: } \frac{\Delta S E 270}{\Delta S E 011}=-\frac{0,0936 S E 270}{0,9996 S E 011} \text {. }
\end{aligned}
$$

The marginal rates of substitution with varying intensity of the labour factor were calculated on the basis of the above equations (Table 2). 
Based on the calculations shown in Table 2, it transpires that, in the reference period, an increase in labour input triggered a decreased demand for capital in both types of farm. The marginal rate of substitution is falling, which implies that the capital intensity of substitution grows with the dropping input of labour. One should note that a decrease in the labour input to the level of 4500 man-hours has triggered only a slight growth in capital. This implies that the amount of capital needed to substitute one hour of human labour is not constant but increases together with decreasing labour. This, in turn, leads to the conclusion that the labour factor value depends on the marginal rate of substitution, and on the production flexibility in relation to both factors. Assuming the average input of labour in farms classified as the "Fieldcrops" group, in order to substitute one man-hour, per-man-hour capital had to be increased by PLN 5.98 in 2009, by PLN 6.88 in 2010 and by PLN 2.55 in 2011, and in the "Mixed" type farms by PLN 2.12, PLN 2.91 and PLN 2.89, respectively. This shows that the substitution of labour for capital was more expensive in the commercial farms classified as the "Fieldcrops" group, as compared to the "Mixed" type farms in 2009 and in 2010 , whereas in 2011 it reached comparable levels in both types of farms. In 2011, the "Fieldcrops" farms faced more favourable conditions to substitute labour by capital as the capital incurred brings more benefits when the rate of substitution is lower.

Table 2. The marginal rates of capital (SE270) for labour (SE011) substitution (MRS) in the "Fieldcrops" and "Mixed" in the years 2009-2011 in Poland

\begin{tabular}{|c|c|c|c|c|c|c|c|c|}
\hline \multicolumn{3}{|c|}{2009} & \multicolumn{3}{|c|}{2010} & \multicolumn{3}{|c|}{2011} \\
\hline SE011 & SE270 & MRS & SE011 & SE270 & MRS & SE011 & SE270 & MRS \\
\hline \multicolumn{9}{|c|}{ "Fieldcrops" } \\
\hline 500 & 246671 & -70.00 & 500 & 266095 & -87.06 & 500 & 235608 & -25.32 \\
\hline 2500 & 196313 & -11.14 & 2500 & 204499 & -13.38 & 2500 & 216088 & -4.64 \\
\hline 4500 & 180605 & -5.69 & 4500 & 185751 & -6.75 & 4500 & 209370 & -2.50 \\
\hline 6500 & 171424 & -3.74 & 6500 & 174906 & -4.40 & 6500 & 205273 & -1.70 \\
\hline 8500 & 165022 & -2.75 & 8500 & 167396 & -3.22 & 8500 & 202336 & -1.28 \\
\hline 10500 & 160148 & -2.16 & 10500 & 161708 & -2.52 & 10500 & 200051 & -1.02 \\
\hline 12500 & 156235 & -1.77 & 12500 & 157161 & -2.06 & 12500 & 198186 & -0.85 \\
\hline $\begin{array}{c}\text { Average: } \\
4313\end{array}$ & 181696 & -5.98 & $\begin{array}{c}\text { Average: } \\
4432\end{array}$ & 186214 & -6.87 & $\begin{array}{c}\text { Average: } \\
4423\end{array}$ & 209564 & -2.55 \\
\hline \multicolumn{9}{|c|}{ "Mixed" } \\
\hline 500 & 130327 & -20.66 & 500 & 145055 & -31.46 & 500 & 160931 & -30.14 \\
\hline 2500 & 114715 & -3.64 & 2500 & 121827 & -5.28 & 2500 & 138417 & -5.18 \\
\hline 4500 & 109491 & -1.93 & 4500 & 114305 & -2.75 & 4500 & 131004 & -2.73 \\
\hline 6500 & 106345 & -1.30 & 6500 & 109837 & -1.83 & 6500 & 126570 & -1.82 \\
\hline 8500 & 104108 & -0.97 & 8500 & 106688 & -1.36 & 8500 & 123431 & -1.36 \\
\hline 10500 & 102378 & -0.77 & 10500 & 104271 & -1.08 & 10500 & 121012 & -1.08 \\
\hline 12500 & 100973 & -0.64 & 12500 & 102319 & -0.89 & 12500 & 119053 & -0.89 \\
\hline $\begin{array}{c}\text { Average: } \\
4120\end{array}$ & 110260 & -2.12 & $\begin{array}{c}\text { Average: } \\
4283\end{array}$ & 114919 & -2.91 & $\begin{array}{c}\text { Average: } \\
4265\end{array}$ & 131664 & -2.89 \\
\hline
\end{tabular}

Source: own study based on empirical unit data from the Polish FADN

\section{SUMMARY AND CONCLUSIONS}

In the reference period 2009-2011, the Polish commercial farms which, according to the Polish FADN, are classified as the "Fieldcrops" farms, as compared to the "Mixed" type farms, displayed higher total outputs, together with higher inputs of labour and capital. The study features a comparative analysis and assessment of the substitution of labour for capital in both the "Fieldcrops" and "Mixed" type farms in Poland, in 2009-2011, based on which the following conclusions can be drawn:

1. Considering the flexibility ratios, reflecting the degree of proportionality of revenue in relation to the analysed factors, it can be inferred that the farms in question displayed a growing efficiency of total inputs in the reference years. In 2009-2011, an increase in the input of production factors by $1 \%$ triggered a growth in output of $1.1187 \%$, $1.1224 \%$ and $1.0413 \%$ in the farms classified as the "Fieldcrops" group, and of $1.0986 \%, 1.1163 \%$ and $1.0932 \%$ in the "Mixed" type farms. The production factors surveyed had a positive impact on total output. As a result, it is advisable to increase their share in the production processes in both the "Fieldcrops" and "Mixed" type farms.

2. Under current circumstances, the substitution of labour for capital was beneficial in both the "Fieldcrops" and "Mixed" type farms, as it reflected the implementation of the strategy of minimising the own production costs along with the maximisation of the production scale. However, the analysis of the substitution of labour for capital in the surveyed commercial farms oriented towards crop production revealed less favourable results, in terms of the achievement of the economic objective in 2009-2011.

3. In the reference period, the marginal rate of the substitution of labour for capital was varied in the types of farms surveyed. In order to substitute one man-hour, an average "Fieldcrops" farm had to increase its per-man-hour capital 
by PLN 5.98 in 2009, by 6.88 in 2010 and by 2.55 in 2011 whereas in the "Mixed" type farm it was PLN 2.12, PLN 2.91 and PLN 2.89, respectively. The substitution of labour for capital was more expensive on the commercial farms classified as the "Fieldcrops" group, as compared to the "Mixed" type farms, in 2009 and 2010 whereas in 2011 it reached comparable levels in both groups. The capital incurred brings more benefits when the rate of substitution is lower, which means that in 2011 the "Fieldcrops" farms faced more favourable conditions to substitute labour for capital.

\section{REFERENCES}

1. Aggelopoulos, S., Zioganas, M., Karipidis, P. 2006. Productivity analysis of pig farms in Greece in conjunction with their size. New Medit. Vol. 3, pp. 53-58.

2. Bezat, A., Rembisz, W. 2011. An implementation of the Cobb-Douglas production function in evaluation of the factor-product relationship in agricultural production. Komunikaty, Raporty, Ekspertyzy, No 557, IERiGŻ, Warszawa.

3. Heady, E., Dillon, J. 1961. Agriculture Production Functions. The Iowa State University Press, Iowa.

4. Heijman, W., Krzyżanowska, Z., Gędek, S., Kowalski, Z. 2007. Agricultural economics. Theoretical review. Fundacja Rozwój SGGW, Warszawa. (In Polish)

5. Ionita, I., Andrei, J. 2010. Using Cobb-Douglass Function in Romanian Agriculture. A descriptive Analysis. Bulletin UASVM Horticulture, Vol. 67, Iss. 2, pp. 117-124.

6. Jaworski, J. 1972. Decision-making aspects of the Cobb-Douglas production function. Przeglad Statystyczny, z. 4.

7. Kalinowski, S. 2002. Implementation of Cobb-Douglas function for production process analyses in polish companies. Ruch Prawniczy, Ekonomiczny i Socjologiczny, Vol. 1, pp. 167-185.

8. Klein, L. R. 1965. An Introduction to Econometrics. PWE, Warszawa.

9. Kotulič, R., Pavelková, J. 2014. The application of the Cobb-Douglas production function in analyzing the effectiveness of productive resources in agricultural enterprises of primary production. Journal of Central European Agriculture, Vol. 15, Iss. 3, pp. 284-301. http://dx.doi.org/10.5513/JCEA01/15.3.1489

10. Mickiewicz, B. 2012. Characteristics of animal husbandry according to Common Agricultural Census from 2002 and 2010. Polityki Europejskie Finanse i Marketing, Zeszyty Naukowe Szkoły Głównej Gospodarstwa Wiejskiego w Warszawie, Vol. 8, Iss. 57, pp. 322-332.

11. Miller, E. 2008. An Assessment of CES and Cobb-Douglas Production Functions. Working Paper, Congressional Budget Office. 30 p.

12. Niezgoda, D. 1986. The economics of substitution in agriculture. PWE, Warszawa.

13. Samuelson, P., Northaus, W. 2004. Economics T. 1. Wydawnictwo Naukowe PWN, Warszawa.

14. Statistical Yearbook of Agriculture 2012. Central Statistical Office of Poland. Available at http://stat.gov.pl/obszarytematyczne/roczniki-statystyczne/roczniki-statystyczne/rocznik-statystyczny-rolnictwa-2012,6,6.html (accessed on 01/10/2015).

15. Statistical Yearbook of Agriculture 2014. Central Statistical Office of Poland. Available at http://stat.gov.pl/obszarytematyczne/roczniki-statystyczne/roczniki-statystyczne/rocznik-statystyczny-rolnictwa-2014,6,8.html (accessed on 26/05/2015).

16. Szulce, H. 2001. Determinants and risk control capabilities in agricultural production. Wyd. Akademii Ekonomicznej w Poznaniu, Poznań.

17. Woś, A. 2003. Agro-environmental policy and new opportunities for agriculture. IERiGŻ-PIB, Warszawa.

18. Wójcik, E. 2005. Determinants of competitiveness of farms. The methods of construction and evaluation of the company's competitive position, Wydawnictwo KEiOA AR Lublin, pp. 487-506.

19. Yuan, Z. 2011. Analysis of agricultural input-output based on Cobb-Douglas production function in Hebei Province, North China. African Journal of Microbiology Research, Vol. 5, Iss. 32, pp. 5916-5922.

20. Zellner, A., Kmenta, J., Dreze, J. 1966. Specification and estimation of Cobb-Douglas production function models. Econometrica, Vol. 34, No. 4, pp. 784-795. http://dx.doi.org/10.2307/1910099 